\title{
ALAT PERANGKAP HAMA DENGAN METODE CAHAYA UV DAN SUMBER LISTRIK PANEL SURYA
}

\author{
WAHYU ALAMSYAH, OTONG NURHILAL, JAJAT YUDA MINDARA, ASWAD HI SAAD, \\ SETIANTO, SAHRUL HIDAYAT ${ }^{*}$ \\ Departemen Fisika Fakultas MIPA Universitas Padjadjaran, \\ Jl. Raya Bandung-Sumedang Km 21, Jatinangor 45363 \\ *email :sahrul@unpad.ac.id
}

\begin{abstract}
Abstrak. Pada kegiatan pengabdian pada masyarakat ini, telah berhasil didesain dan dibuat alat perangkap hama dengan basis cahaya UV yang sumber listriknya dari panel surya. Untuk memudahkan di dalam penggunaannya, alat telah dilengkapi dengan kontroler sehingga pengisian baterai dan penyalaan lampu dapat diatur waktunya secara otomatis. Berdasarkan hasil pengujian yang telah dilakukan, alat dapat berfungsi dengan baik, yaitu pengisian baterai berlangsung normal dan pada saat matahari terbenam, secara otomatis lampu UV menyala selama 10 jam. Setelah menyala 10 jam lampu UV akan mati secara otomatis untuk menghemat dan mengefisiensikan daya listrik yang digunakan. Berdasarkan hasil pengujian alat telah berfungsi dengan baik dan dapat menjebak hama yang biasa aktif di malam hari.
\end{abstract}

Kata kunci : perangkap hama, cahaya UV, panel surya

\begin{abstract}
.
In the community service activities has successfully designed and manufactured instrument for insect trapping using UV light with the electricity source from solar panels. For simplicity in use, the instrument has been equipped with a controller so the battery charging and the lighting can be switched automatically. Our experiments have resulted the instrument that well function, the charging of battery switch normally and at sunset and automatically turns on the UV lamp for 10 hours. The UV lamp turn on for 10 hours and then turn off automatically to save the electricity.
\end{abstract}

Keywords : insect trapping, UV light, solar panels

\section{Pendahuluan}

Budidaya tanaman padi merupakan hal yang sangat penting untuk menjamin ketahanan pangan masyarakat Indonesia. Padi atau beras telah menjadi sumber pangan pokok bagi masyarakat Indonesia. Salah satu masalah yang dapat mengurangi produksi padi adalah adanya serangan hama serangga atau wereng. Serangan hama wereng pada tanaman padi semakin ke sini semakin meningkat. Di beberapa wilayah di Jawa Barat seperti Karawang, Subang dan Majalengka, hama wereng telah merusak puluhan bahkan ratusan hektar sawah petani. Produksi sawah yang seharusnya 6.2 ton/ha, karena serangan hama wereng hanya mampu mencapai 5.4 ton/ha [1]. Petani mengalami kerugian dan ketersediaan pangan nasional pun terancam berkurang.

Wereng adalah sebutan umum untuk serangga penghisap cairan tumbuhan dengan ukuran tubuh yang kecil. Terdapat beberapa jenis hama wereng, beberapa 
diantaranya yang paling terkenal adalah wereng hijau dan wereng coklat. Wereng hanya bisa hidup dengan menghisap cairan tumbuhan, dengan demikian wereng hidup dengan merusak tanaman. Wereng menjadi hama yang ditakuti dalam budidaya tanaman, selain sebagai pemakan langsung, wereng juga menjadi vektor bagi penularan sejumlah penyakit tumbuhan dari kelompok virus. Wereng memiliki kemampuan adaptasi yang tinggi terhadap kondisi lingkungannya. Bahkan, suatu jenis wereng mampu menghasilkan keturunan yang tahan terhadap kondisi tertentu [1].

Wereng menjadi hama padi yang paling berbahaya dan paling sulit dikendalikan apalagi dibasmi. Sulitnya memberantas hama padi tersebut karena wereng mempunyai daya perkembangbiakan yang cepat dan cepat menyesuaikan diri terhadap perubahan lingkungan. Tidak jarang, hama tahan terhadap berbagai insektisida dan pestisida, sehingga sering kali para petani memberikan dosis pestisida yang berlipat ganda bahkan dengan mengoplos beberapa merk pestisida sekaligus. Dan semua usaha pengendalian dan pengobatan dengan menggunakan pestisida itu tidak pernah berhasil tuntas membasmi wereng, bahkan mengakibatkan wereng menjadi kabal.

Penggunaan varietas bibit padi yang tahan hama juga tidak dapat bertahan lama dan terus menerus. Sekali dua kali musim tanam memang varietas padi tahan wereng mampu melawan, tetapi untuk selanjutnya varietas tersebut pun biasanya takluk oleh wereng, karena wereng memiliki kemampuan beradaptasi yang cepat terhadap lingkungannya.

Alternatif lain yang biasa digunakan para petani untuk membasmi serangga hama yang tidak merusak lingkungan adalah menggunakan lampu pada malam hari sebagai media perangkap belalang. Sumber energi listrik lampu adalah generator dengan bahan bakar premium. Tetapi, dengan cara ini para petani harus mengeluarkan dana tambahan untuk menyediakan bahan bakar premium yang harganya cukup mahal.

Energi listrik yang digunakan untuk menyalakan lampu sebenarnya bisa diperoleh dari tenaga matahari yakni dengan memanfaatkan panel surya. Panel surya akan menyimpan energi listrik pada aki di siang hari dan pada malam harinya bisa digunakan untuk menyalakan lampu. Dengan demikian petani tidak mengeluarkan biaya tambahan untuk.

Berdasarkan hasil penelitian sebelumnya telah diketahui bahwa serangga hama atau secara umum serangga memiliki sifat tertarik terhadap berkas cahaya UV [1]. Pada kegiatan pengabdian kepada masyarakat ini akan dilakukan rancang bangun alat perangkap belalang hama padi berbasis cahaya UV dan penyuluhan pemanfaatannya pada petani di desa Panjalin Kidul Kecamatan Sumberjaya Kabupaten Majalengka.

\section{Metode Penelitian}

Untuk membantu mengatasi hama serangga (wereng) diusulkan solusi untuk membuat alat perangkap hama serangga dengan metode UV-light trapping. Sumber listrik untuk lampu diperoleh dari panel surya yang disimpan di dalam baterai. Prinsip perangkap ini adalah memanfaatkan sifat hama serangga atau ngengat yang aktif pada malam hari. Secara alami ngengat penggerek batang padi 
atau hama jenis lainnya mudah tertarik dengan cahaya. Cahaya lampu-UV berfungsi untuk menarik hama yang aktif pada malam hari. Hama yang mendekat akan menabrak lampu dan akan jatuh ke bawah. Dibawah lampu dipasang corong yang tersambung dengan kantong plastik untuk menampung hama. Hama yang sudah masuk ke kantong plastik akan terperangkap dan sulit keluar. Selain itu, perangkap dirancang bekerja secara otomatis, yaitu menyala mulai jam enam sore hingga jam enam pagi. Keunggulan dari metode yang ditawarkan adalah sebagai berikut [4]:

- Arus rendah (DC) sehingga aman atau tidak berbahaya bagi petani

- Dapat digunakan untuk area sawah yang jauh dari jangkauan PLN, karena sumber listrik berasal dari panel surya

- Berkas cahaya lampu sudah sesuai dengan keinginan hama, yang secara alami sensitive terhadap warna biru-UV.

- Alat yang dirancang awet dan dapat beroperasi dalam jangka yang panjang

- Alat dirancang dapat bekerja secara otomatis, yaitu menyala mulai jam enam sore dan mati pada jam enam pagi

- Alat yang dirancang adalah untuk tanaman padi, tetapi dapat juga digunakan untuk pengendalian hama pada tanaman bawang merah, cabe, kubis, bungkul, sawi, kedele, perkebunan manga, dll

- Alat bisa juga digunakan untuk penerangan jalan di area sawah yang bermanfaat pada saat panen raya

- Alat tetap dapat berjalan walaupun aliran listrik PLN mati

Desain dari alat yang dirancang diperlihatkan pada Gambar 1

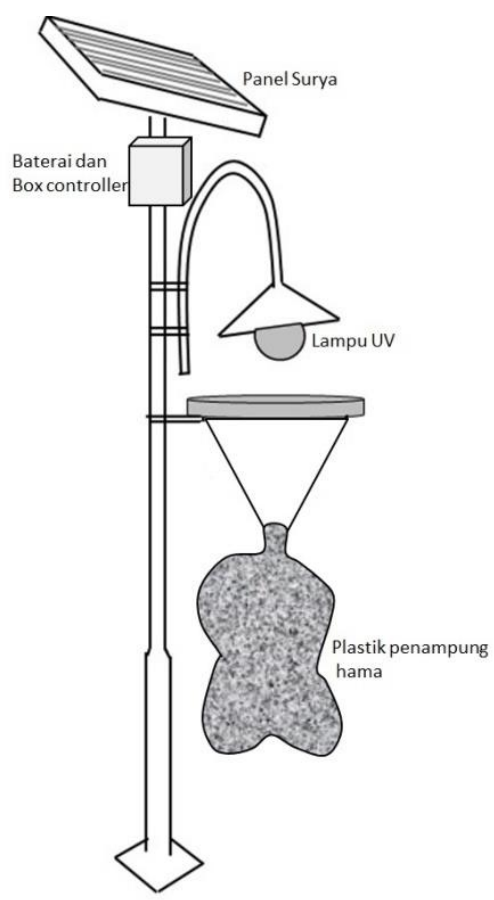

Gambar 1. Rancangan alat Penjebak Hama dengan metode $U V$-light trapping 
Alat pada Gambar 1 dirancang untuk menangkap serangga dalam keadaan hidup, selanjutnya dapat diseleksi serangga yang merupakan hama dan serangga predator. Alat tersebut dirancang dengan mempertimbangkan keseimbangan lingkungan, yaitu serangga yang bermanfaat bagi kelestarian ekosistem sawah dapat dilepas kembali, sedangkan serangga hama yang merusak tanaman dapat dimusnahkan dengan cara dikubur. Beberapa serangga yang bermanfaat sebagai predator hama diantaranya adalah: Kepik permukaan air (Microvellia douglasi), Kepik mirid (Cyrtorhinus lividipennis), Kumbang stacfilinea (Paederus fuscipes), Kumbang koksinelid (Synharmonia octomaculata), Kumbang tanah atau kumbang karabid (Ophionea nigrofasciata), Serangga bertanduk panjang (Conocephalous longipennis), Capung kecil atau kinjeng dom (Agriocnemis spp.) [2].

Solusi kedua akan dirancang alat prangkap serangga yang lebih sederhana yaitu dengan menjebak serangga dalam larutan detergen. Serangga akan tertarik dengan cahaya lampu UV dan akan terjebak masuk ke dalam larutan deterjen, selanjutnya akan mati. Alat penjebak tersebut dapat digunakan untuk pengendalian hama jangka pendek, yaitu pada saat serangan hama mewabah. Gambar alat yang dirancang adalah sebagai berikut:

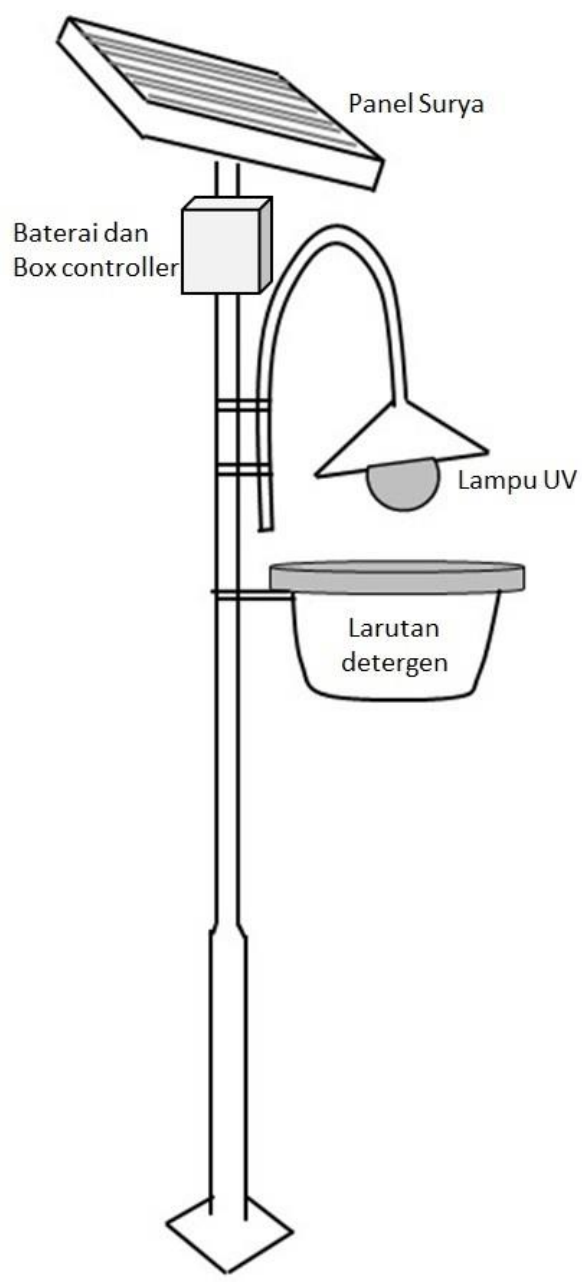

Gambar 2. Rancangan alat Penjebak Hama dengan larutan detergen 
Manfaat dari kegiatan ini adalah memberikan solusi metode pengendalian hama yang lebih ramah lingkungan bagi kelompok petani di Desa Panjalin Kidul Kecamatan Sumberjaya Kabupaten Majalengka. Melalui kegiatan ini akan diberikan bantuan alat perangkap hama sebagai model yang selanjutnya dapat direplikasi oleh kelompok petani secara mandiri. Selain bantuan alat berupa teknologi tepat guna, telah dilakukan penyuluhan berupa pengendalian hama yang ramah lingkungan dengan memperhatikan keseimbangan ekosistem di area pertanian.

\section{Hasil dan Pembahasan}

Alat perangkap hama terdiri dari tiang dudukan panel surya, tempat baterai dan kontroler serta dudukan lampu. Tiang penyangga panel surya dibuat dari besi kotak hollow, dilas dan disesuaikan dengan ukuran panel surya. Untuk dudukan bawah, dibuat fleksibel sehingga kalau tidak dipakai dapat dilepas dan disimpan ditempat aman atau dipasang ditempat lain. Tiang penyangga bagian bawah juga dilengkapi dengan kunci dan dapat digembok untuk pengamanan. Semua komponen dudukan panel surya dan tempat baterai/kontroler dicat warna hitam untuk menjaga supya tidak mudah berkarat.

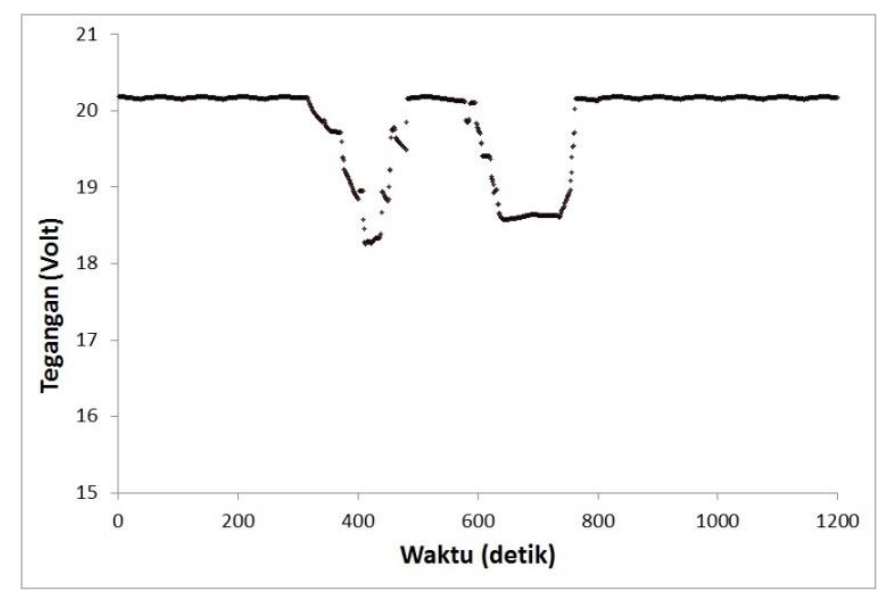

Gambar 3. Karakteristik Tegangan Keluaran Panel Surya tanpa beban lampu

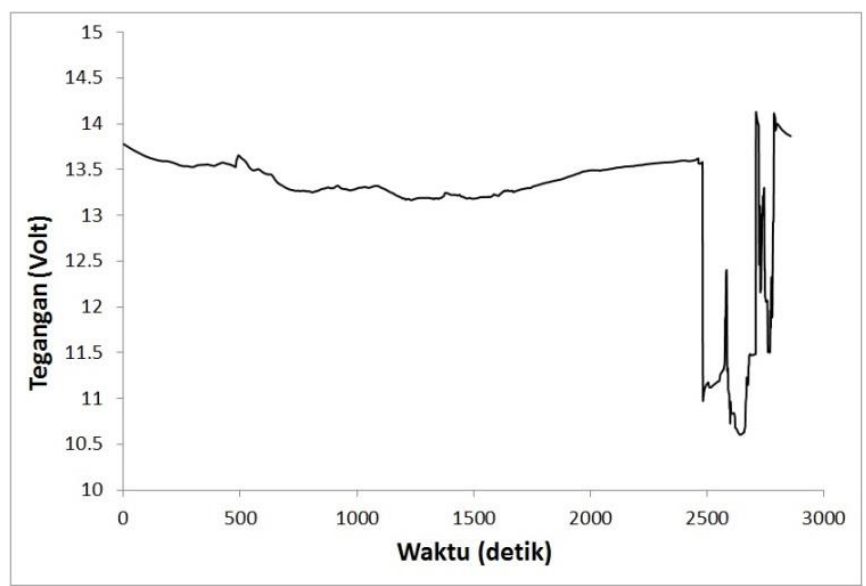

Gambar 4. Karakteristik Tegangan Keluaran Panel Surya dengan beban lampu UV 


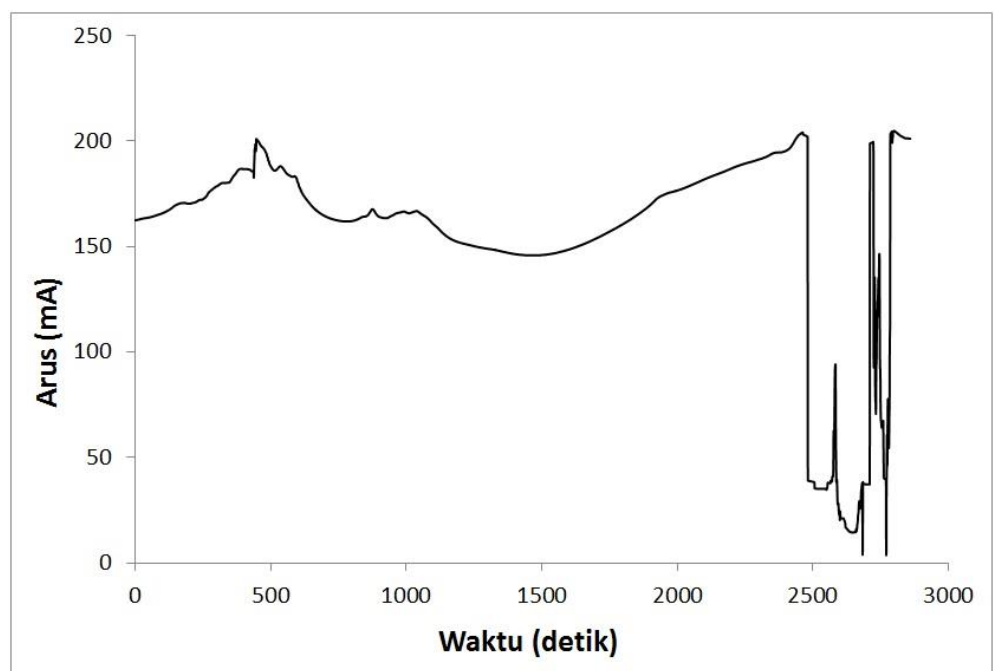

Gambar 5. Karakteristik Arus Keluaran Panel Surya dengan beban lampu UV

Setelah semua komponen lengkap, selanjutnya dilakukan pemasangan dan pengecekan kinerja alat. Pengujian dilakukan di kampus untuk memastikan semua kompenen berjalan dengan normal sebelum dipasang di lokasi. Pengecekan yang dilakukan terdiri dari kesesuaian ukuran dan jarak antar komponen, proses pengisian panel surya ke baterai dan otomatisasi nyala dan matinya lampu. Pada kegiatan Pengabdian pada Masyarakat ini dibuat empat set alat untuk percontohan di alat perangkap hama di Desa Panjalin Kidul Kecamatan Sumberjaya, Majalengka. Keempat alat yang telah dibuat akan dihibahkan kepada kelompok tani dan dapat dipergunakan serta direplikasi untuk membantu kelompok petani lainnya.

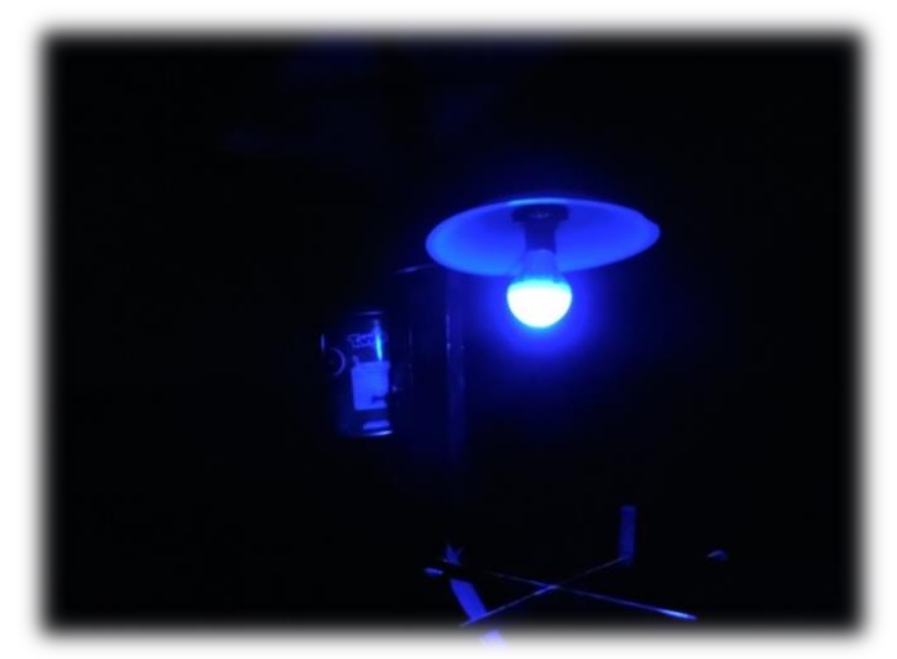

Gambar 3. Uji kontroler otomatisasi penyalaan lampu UV

Setelah dilakukan pengujian dan telah dipastikan semua komponen dan keseluruhan alat dapat bekerja dengan normal, selanjutnya alat dibawa ke lokasi. 
Di lokasi dilakukan penentuan tempat untuk pemasangan alat perangkap hama dengan berkoordinasi bersama kelompok tani di desa Panjalin Kidul Kecamatan Sumberjaya Majalengka. Beberapa bahan yang dibutuhkan untuk pemasangan alat dilokasi diantaranya adalah semen, pasir, bata dan besi beton. Bahan-bahan tersebut dibutuhkan untuk pemasangan dudukan alat supaya kokoh serta aman.

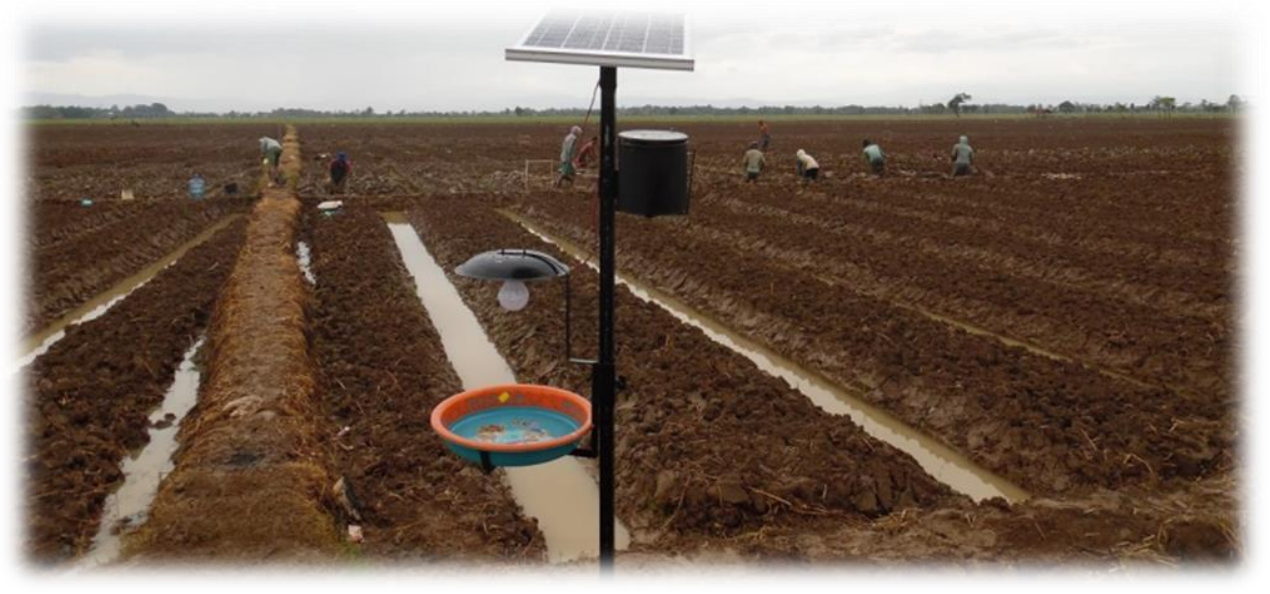

Gambar 4. Lokasi pemasangan alat perangkat hama

\section{Kesimpulan}

Telah berhasil didesain dan dibuat alat perangkap hama dengan basis cahaya UV yang sumber listriknya dari panel surya. Untuk memudahkan di dalam penggunaannya, alat telah dilengkapi dengan kontroler sehingga pengisian baterai dan penyalaan lampu dapat diatur waktunya secara otomatis. Berdasarkan hasil pengujian yang telah dilakukan, alat dapat berfungsi dengan baik, yaitu pengisian baterai berlangsung normal dan pada saat matahari terbenam, secara otomatis lampu UV menyala selama 10 jam. Setelah menyala 10 jam lampu UV akan mati secara otomatis untuk menghemat dan mengefisiensikan daya listrik yang digunakam. Berdasarkan hasil pengujian alat telah berfungsi dengan baik dan dapat menjebak hama yang biasa aktif di malam hari.

\section{Ucapan terima kasih}

Terima kasih kepada Direktorat Penelitian dan Pengabdian Kepada Masyarakat Universitas Padjadjaran atas bantuan dana dalam penelitian ini melalui Hibah PPM Perioritas tahun 2016.

\section{Daftar Pustaka}

1. http://benihpertiwi.co.id/hama-penggerek-batang-padi-sundep-beluk/. Akses tanggal 31 Maret 2016

2. http://bbpadi.litbang.pertanian.go.id/index.php/berita/info-aktual/content/113deteksi-awal-hama-gunakan-lampu-perangkap. Akses tanggal 31 Maret 2016

3. Jerome Hogsette. Ultraviolet Light Traps: Design Affects Attraction And Capture. Proceedings of the Sixth International Conference on Urban Pests, Hungary. 2008. 
4. Pickens, L. G. and Thimijan, R. W. Design parameters that affect the performance of UV-emitting traps in attracting house flies (Diptera: Muscidae). J. Econ. Entomol. 79: 1003-1009. 1986.

5. http://i.litbang.pertanian.go.id/berita/2203/. Judul Artikel: Uji Kelayakan Lampu Perangkap Hama Static Solar Cell dan Electric. Akses tanggal 31 Maret 2016

6. https://id.wikipedia.org/wiki/Wereng. Akses tanggal 31 Maret 2016 